\title{
Evaluation of the electro-removal technique of the treated wood using the accelerated decaying fungus test
}

\author{
Avaliação da técnica de eletrorremoção da madeira tratada utilizando o \\ ensaio de apodrecimento acelerado
}

\author{
Luana Candaten $^{1}$ (D), Fernando Nunes Gouveia ${ }^{2}$ (D), Anna Sofya Vanessa Silvério da Silva ${ }^{2}$ (1), \\ Marcelo Fontana da Silveira² (10, José Roberto Victor de Oliveira² (1D, Rômulo Trevisan ${ }^{1}$ (1), \\ Paulo Roberto da Silva Bairros ${ }^{1}$ (D), Arci Dirceu Wastowski ${ }^{1}$ (i) \\ ${ }^{1}$ Universidade Federal de Santa Maria - UFSM, Frederico Westphalen, RS, Brasil \\ ${ }^{2}$ Laboratório de Produtos Florestais - LPF, Serviço Florestal Brasileiro - SFB, Brasília, DF, Brasil
}

\begin{abstract}
How to cite: Candaten, L., Gouveia, F. N., Silva, A. S. V. S., Silveira, M. F., Oliveira, J. R. V., Trevisan, R., Bairros, P. R. S., \& Wastowski, A. D. (2021). Evaluation of the electro-removal technique of the treated wood using the accelerated decaying fungus test. Scientia Forestalis, 49(132), e3738. https://doi.org/10.18671/scifor.v49n132.14
\end{abstract}

\begin{abstract}
The most used wood preservative in the country is Chromated Copper Arsenate (CCA), and the disposal of treated wood becomes a major concern, due mainly to the presence of arsenic. Thus, the objective of the present work was to apply a technique for the electro-removal of heavy metals from wood samples treated with CCA and to evaluate the feasibility of this procedure. For that, samples of Eucalyptus grandis treated with CCA, by the full cell process on industrial scale, were submitted to electro-removal, which consists in the application of an electric current in a mixture of acids, oxalic and phosphoric, in permanent agitation. In order to monitor the effectiveness of the technique, the concentration of copper, chromium and arsenic in the samples was measured, before and after the process of electro-removal, through the analysis of dispersive energy spectrophotometry. Three groups of samples were created to evaluate the efficiency of the electro-removal technique: untreated wood, treated with CCA, and submitted to electroremoval. These samples were exposed to the white rot fungus Trametes versicolor in a laboratory accelerated decaying test based on ASTM 2017-05. The results showed that the electro-removal technique promoted the removal of $52.92 \%$ copper, $31.63 \%$ chromium and $52.64 \%$ arsenic from the wood treated with CCA, however, the biological assay did not present statistical difference between the treatments, with and without electro-removal, differing only from the control samples, although the fungal development was greater in the material in which the technique was applied than in Eucalyptus with CCA without removal. The accelerated decaying test mass loss was $11.26 \%$ for the wood treated with CCA, $13.44 \%$ for the samples submitted to electro-removal and $61.77 \%$ for the control samples. The electro-removal technique proved to be promising and more studies are recommended regarding the sample size and other variables.
\end{abstract}

Keywords: Wood preservation; Hazardous waste; Decay test; Electro-remediation; Trametes versicolor.

\section{Resumo}

O preservativo de madeira mais utilizado no país é o Arseniato de Cobre Cromado (CCA), e o descarte da madeira tratada torna-se uma grande preocupação, principalmente devido à presença de arsênio. Assim, o objetivo do presente trabalho foi aplicar uma técnica de eletrorremoção de metais pesados de amostras de madeira tratadas com CCA e avaliar a viabilidade desse procedimento. Para tanto, amostras de Eucalyptus grandis tratadas com CCA, pelo processo de célula cheia, em escala industrial, foram

Financial support: This work was supported by the Conselho Nacional de Desenvolvimento Científico e Tecnológico (CNPq), of Programa Institucional de Bolsas de Iniciação Científica (PIBIC), process n 139810/2018-8, maintained by the Brazilian Forestry Service, Forest Products Laboratory (SFB/LPF).

Conflict of interest: Nothing to declare.

Corresponding author: luana_candaten@outlook.com

Received: 21 June 2021.

Accepted: 30 August 2021.

Editor: Mauro Valdir Schumacher.

(c) This is an Open Access article distributed under the terms of the Creative Commons Attribution License, which permits unrestricted use,

c) distribution, and reproduction in any medium, provided the original work is properly cited. 
submetidas à eletrorremoção, que consiste na aplicação de corrente elétrica em uma mistura de ácidos oxálico e fosfórico, em constante agitação. Para verificar a eficácia da técnica, foi medida a concentração de cobre, cromo e arsênio nas amostras, antes e após o processo de eletrorremoção, por meio da análise de espectrofotometria de energia dispersiva. Três grupos de amostras foram criados para avaliar a eficiência da técnica de eletrorremoção: madeira não tratada, tratada com CCA e submetida à eletrorremoção. Essas amostras foram expostas ao fungo da podridão branca Trametes versicolor no ensaio de apodrecimento acelerado em laboratório baseado na ASTM 2017-05. Os resultados mostraram que a técnica de eletrorremoção promoveu a remoção de 52,92\% cobre, 31,63\% cromo e 52,64\% arsênio da madeira tratada com CCA, porém, o ensaio biológico não apresentou diferença estatística entre os tratamentos, com e sem eletrorremoção, diferindo apenas nas amostras controle, embora o desenvolvimento fúngico tenha sido maior no material em que a técnica foi aplicada do que no eucalipto com CCA sem remoção. A perda de massa no ensaio de apodrecimento acelerado foi de 11,26\% para a madeira tratada com CCA, 13,44\% para as amostras submetidas à eletrorremoção e $61,77 \%$ para as amostras controle. A técnica de eletrorremoção mostrou-se promissora e mais estudos são recomendados quanto ao tamanho da amostra e outras variáveis.

Palavras-chave: Preservação da madeira; Resíduos perigosos; Ensaio de laboratório; Eletrorremediação; Trametes versicolor.

\section{INTRODUCTION}

Because the natural degradation process that occurs in wood by the action of xylophagous organisms, treatments on the material are necessary, mostly chemical, in order to increase the useful life and exposure in different places of application. The so-called chemical preservatives most used worldwide take into their composition the salts of boron and arsenic metals, being popularly known as Chromated Copper Arsenate (CCA) and Chromated Copper Borate (CCB) (Mohajerani et al., 2018).

These substances present an excellent performance for wood preservation, where Chromium acts as a fixative, and Copper and Arsenic as a fungicide and insecticide, however, because they have metals in their composition, they can be highly toxic to human health and to the environment (Matos et al., 2020; Deramos King et al., 2019). Thus, the volume of material installed throughout the world, even after the reduction of its application due to the legislation of the countries of Europe and USA, still worries, because the material used, in the most varied sectors, has a useful life of up to 50 years (Xing et al., 2020).

The amount of products in use and which have these preservatives in its composition, and the search for the environmentally correct destination of the residues of this treated material still generates uncertainties. The major concern is about wood being replaced by other materials due to the end of its useful life, because both incineration and accumulation in sanitary landfills, commonly used practices, are not ideal. In general, the burning of preserved wood causes serious risks to the environment due to the release of toxic gases and the deposit of this material containing metals in the same place may increase the leaching rates of inappropriate components, such as arsenic (Deramos King et al., 2019) for instance, to the soil (Jones et al., 2019; Xing et al., 2020).

On the other hand, since wood is a renewable natural resource, it should be widely used in the most varied segments and not simply replaced by elements such as concrete and steel, for instance. Thus, investigations aiming at solutions for the final destination or reuse of correctly treated wood waste are of fundamental importance for the sector and should be encouraged (Xing et al., 2020).

Some procedures that extract the metals present in the material preserved with CCA have already been studied for some time (Janin et al., 2012; Coudert et al., 2013), but results are still scarce and should be better elucidated. An innovative alternative to verify their effectiveness would be the use of xylophagous organisms after the extraction of the chemical species $\mathrm{Cu}$, $\mathrm{Cr}$ and As from preserved wood in order to assure the non-toxicity of the compound.

The use of the white rot fungus Trametes versicolor in the process of evaluation of the efficacy of the technique consists in the fact that the species and fungal strains differ in their sensitivity to metals and in the protection mechanisms involved and, in general, brown rot fungi may be more tolerant to certain wood preservatives, such as CCA, since they produce 
oxalic acid in the degradation process on a larger scale than do white rot fungi. Oxalic acid is involved in the promoted detoxification process (Baldrian, 2003; Sierra-Alvarez, 2007; Lebow et al., 2012). In view of this, the choice of the white rot fungus, Trametes versicolor, allowed for more security in the evaluation of the viability of the technique.

The electro-removal technique recently received attention (Santos et al., 2018), and this procedure uses organic acids (citric, acetic, formic, oxalic, fumaric, tartaric, gluconic and maleic acids) and mineral acids (sulfuric, hydrochloric, nitric and phosphoric) (Ferrarini, 2012). Oxalic acid is one of the most used ones in the procedure and when associated with sulfuric and phosphoric acids or sodium oxalate, it can remove, in fractional samples of wood treated with CCA, somewhere between $98 \%$ and $100 \%$ of arsenic and 88 to $100 \%$ of chromium and copper, (Kakitani et al., 2006a, 2006b).

Studies on the economic viability of the process showed that the technique can be economically viable, depending on the location and material in which it is applied Janin et al., 2012; Ferrarini, et al., 2016). In this context, this study evaluated the feasibility of using the electro-removal technique, for the extraction of chemical components from wood treated with CCA, associated with the technique of accelerated decaying by fungi.

\section{MATERIAL AND METHODS}

\section{Preparation of the material}

To conduct the study we used 3 Eucalyptus grandis logs from which four baguettes were removed, with dimensions of $2.5 \mathrm{~cm} \times 2.5 \mathrm{~cm} \times 20 \mathrm{~cm}$ in thickness, width and length, respectively, as shown in Figure 1. After preparation the material was submitted to chemical treatment, with the CCA type preservative, by the vacuum and pressure method in an industrial autoclave, with retention of $9.5 \mathrm{~kg} \mathrm{~m}^{-3}$, such as used commercially.

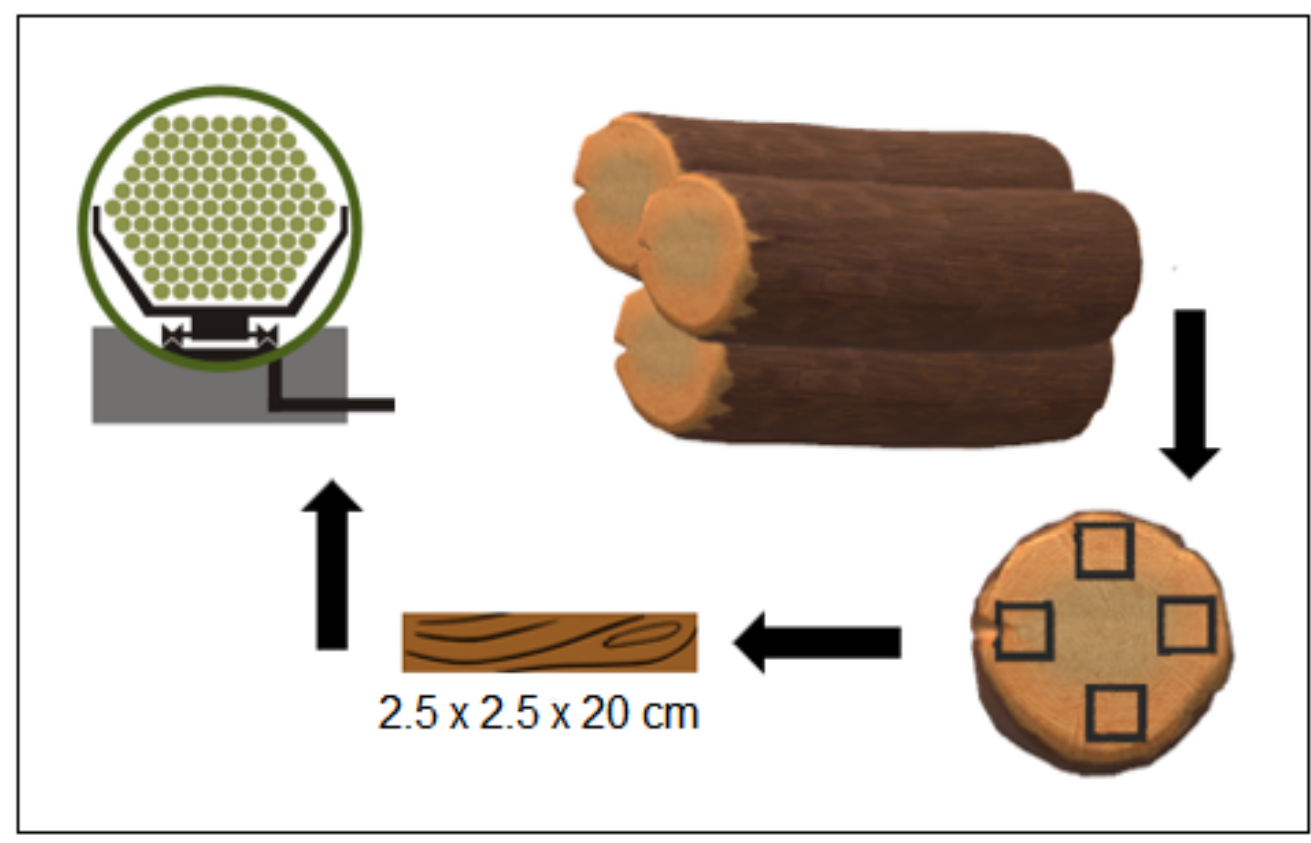

Figure 1: Representative diagram of specimen preparation and treatment in the autoclave.

\section{X-ray spectrometry analysis}

The concentration of the metallic ions, copper, chromium and arsenic, present in the treated baguettes were analyzed by $\mathrm{X}$-ray dispersive energy spectrometry using a spectrometer. The simultaneous collection of data in the wood samples was performed by the 
Fundamental Parameters Method (Younis et al., 2017). This same process was repeated after the application of the electro-removal treatment, to verify the ion concentration difference before and after the procedure.

\section{Electro-removal}

The electro-removal technique was done on a lab scale (Figure 2), where the treated wood was submerged in a solution composed of oxalic acid and phosphoric acid, diluted in 5\% concentration in ultra-pure water.

The mass balance according of the molarity chemical components is $0.6 \mathrm{~mol} / \mathrm{l}$ for oxalic acid and $0.4 \mathrm{~mol} / \mathrm{l}$ for phosphoric acid.

This electrolytic conductive solution was done by a 25 -volt voltage source at $1.5 \mathrm{~A}$, making the transmission of positive and negative charges through graphite electrodes. The samples remained in the solution, in constant agitation, for 4 hours under constant dilution with the aid of a magnetic stirrer. Afterwards, the material was washed with distilled water and dried in air and later in an oven for new measurements of X-ray fluorescence spectrometry in order to obtain the concentrations of the metals.

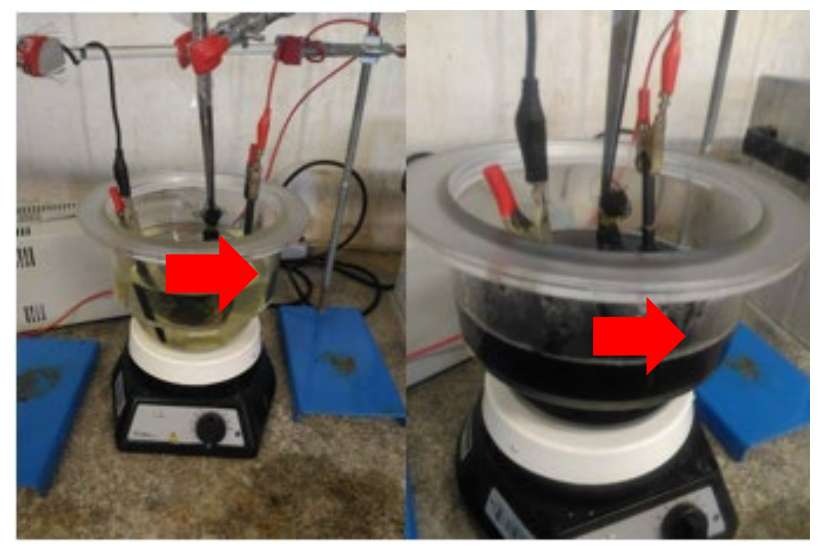

Figure 2. Equipment used at lab scale for the electro-removal process. Notice the figure on the right where the solution appears darker after the application of the electro-removal.

\section{Accelerated decay test}

The specimens were made from the baguettes with and without electro-removal for the accelerated decay test following the recommendations of the modified ASTM D 2017-05 standards. These were carried out at the Forest Products Laboratory of the Brazilian Forest Service. The substrate used was vermiculite, duly sterilized at $121^{\circ} \mathrm{C}$ for 40 minutes and naturally cooled. The substrate was packed in a $250 \mathrm{ml}$ bottle and permeable cap, up to half of the total volume of the container and then hydrated with deionized water, until reaching $130 \%$ water retention capacity. A support plate made with Cecropia sp. wood for the initial development of the white rot fungus Trametes versicolor was added to each flask. Three milliliters of malt extract solution dissolved in deionized water with fungus inoculum were poured over each plate. The containers were then taken to an incubator at $25^{\circ} \mathrm{C}$ and $65 \%$ relative humidity, where they remained for two weeks so that the fungus could develop properly. The flasks were removed from the incubator and, in a laminar flow chamber, they received the non-treated specimens, those impregnated with CCA, and those that were submitted to the process of electro-removal. The flasks returned to the incubator where they remained for 16 weeks. The material was evaluated for loss of mass and the results obtained made it possible to classify them according to the resistance to the attack of the deteriorating agents.

\section{Statistical analysis}

The data were statistically analyzed in a $2 \times 2$ factorial scheme, with the support of the Statgraphics statistical program verifying the influence of the electro-removal treatment in the 
concentrations of the metals before and after the application of the technique, and a Tukey's test of means at 95\% reliability was applied in order to verify the difference between the materials in the accelerated decay test.

\section{RESULTS AND DISCUSSION}

The results obtained regarding the electro-removal of heavy metals from the treated material showed that the chemical extraction process was effective, since there was the detachment of chromium linked to lignin and, in the sequence, of arsenic and copper from the preserved wood (Figure 3).

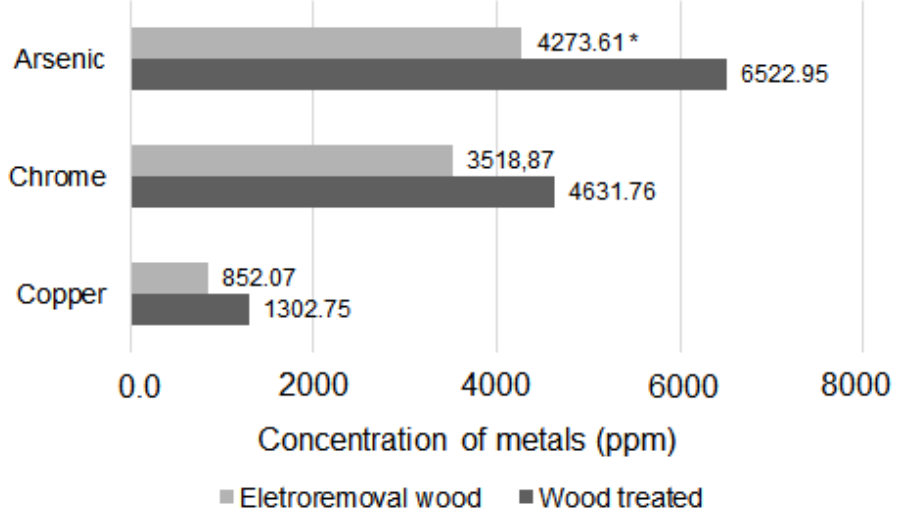

Figure 3: Arsenic, chromium and copper concentrations verified in the materials before and after the electro-removal process. * Statistically significant difference between pre- and post- electro-removal concentration for all metals.

The highest concentration of metals in the treated material, both for the condition with removal and in the samples where the technique was not applied, was observed for arsenic, followed by chromium and copper. However, when the technique was applied, the extraction of the chemical elements was more successful for Copper, presenting a reduction of $34.6 \%$, very similar to arsenic, which decreased $34.5 \%$ after the electro-removal. Chromium, which acts as a fixator of the preservative treatment in the wood, showed a smaller proportion, decreasing in $24.0 \%$ its concentration.

The extraction obtained in the trial were reflected on the results in the biological test, as can be observed in Figure 4. Although the electrode was satisfactory, the biological organism still did not yield an ideal development, indicating that the metal rates that were extracted from wood were still not enough, as they interrupted the development of living organisms and therefore still being harmful to the environment by accumulation or burning of such material.

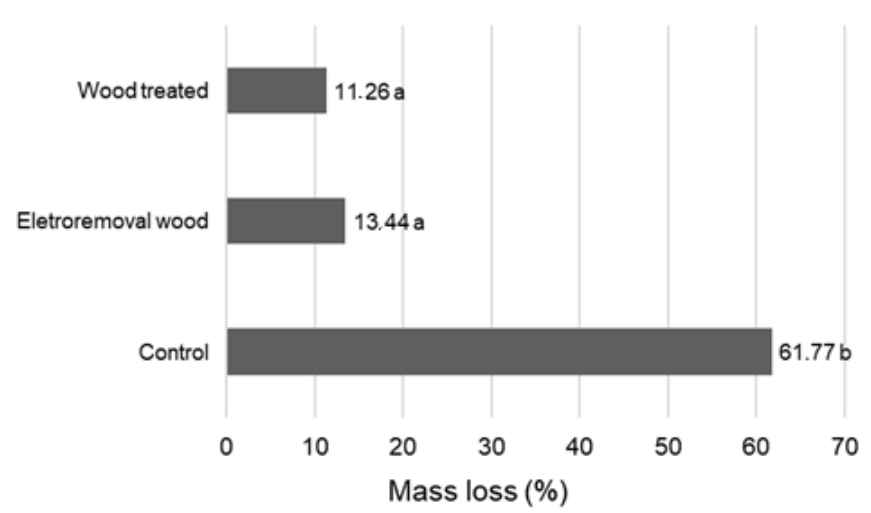

Figure 4. Mass loss averages obtained from the accelerated decaying test in the laboratory with Trametes versicolor fungus. 
Lower case letters next to the averages indicate Tukey's Test result at 5\% error probability. Equal letters are statistically equal; different letter are statistically different.

Other authors found reduction values of these compounds in higher proportions than the one obtained in the present study, varying between 87, 81 and 95\% for copper, chromium and arsenic, respectively (Christensen et al., 2006; Pedersen et al., 2005; Ribeiro et al., 2000; Ottosen et al., 1997). The extraction of metals by the process of electro-removal is linked to several factors, according to the research of Janin et al. (2012), where they reported that the size adopted in the particle during the process is a determining indicator of the removal. Thus, the result obtained in this study, when compared to the authors cited above, can be better understood, since they used fractional material for electrochemical extraction, while in this research the samples were in solid condition and of considerable volume.

Castro et al. (2015) also observed stronger metal reduction values than those obtained in the present study: above $80 \%$ for copper, chromium and arsenic, however, they used a differentiated electrolysis system, combining different acids than those applied in this research and used temperature during the process.

In a similar experiment, Pedersen et al. (2005), obtained a removal of 57, 66 and $85 \%$ for copper, chromium and arsenic, respectively, also using fractionated material, and stated that they reached even more satisfactory values of removal in the treatment in which they increased the voltage used. Furthermore, they tested greater distances between the electrodes and greater volume of mass in the electro-removal, making these conditions reduce the efficiency of the extraction of metals from wood.

The fungal developments and, consequently, the losses of mass, although they did not show statistical differences, occurred in greater proportion in the material with electroremoval, indicating that the fungus had a greater progress in the material with the extraction of the metals, although it was not $100 \%$ or close to that.

Even so, the percentage of removal obtained was not enough for the biological organism development to occur properly, which in the case of totally decontaminated material would be close to $60 \%$ of mass loss, according to the result obtained by the control; which was Eucalyptus grandis wood without chemical treatment.

Such results, when compared to each other, can be explained by the mild removal rate of Chromium, which acts as a fixer of the chemical treatment of Chromated Copper Arsenate in the wood, and consequently, due to its lower extraction scale, the removal of the other metals (Copper and Arsenic). In the electro-removal technique, with the application of electricity, the process of chromium release from the lignin is accelerated, and with this, the exit of other metals is possible.

It is also worth mentioning that the present study was based on recently treated wood, which received the preservative treatment with CCA especially for these trials. The investigation of the electro-removal technique in treated wood taken out of use could present a greater removal of the metals, because of leaching of the same which occurs over time, along with natural weathering. Also, the electro-removal applied to this type of material may be a solution to the accumulated waste of CCA-treated wood that has been removed from use all over the world, expanding applications for reuse.

\section{CONCLUSION}

The proliferation of microorganisms under the decontaminated material occurs more expressively in the control in natura when comparing to treated wood without the application of electro-removal. Electro-removal associated to the test of accelerated decaying with fungus are presented as promising techniques for the recovery of CCA from wood treated with CCA aiming at its final destination as solid residue, allowing the extraction of $\mathrm{Cu}, \mathrm{Cr}$ and $\mathrm{As}$ present in the material. 


\section{REFERENCES}

Baldrian, P. (2003). Interactions of heavy metals with white-rot fungi. Enzyme and Microbial Technology, 32(1), 78-91. http://dx.doi.org/10.1016/S0141-0229(02)00245-4.

Castro, A. M., Pico, F. A., Ribeiro, A. B., Mateus, E. P., \& Oliveira, A. V. (2015). Electrodialytic removal of heavy metals from treated timber waste. In Global Conference on Global Warming, Athens, Greece.

Christensen, I. V., Pedersen, A. J., Ottosen, L. M., \& Ribeiro, A. B. (2006). Electrodialytic remediation of CCA-treated waste wood in a $2 \mathrm{~m}^{3}$ pilot plant. The Science of the Total Environment, 364(1-3), 45-54. http://dx.doi.org/10.1016/j.scitotenv.2005.11.018.

Coudert, L., Blais, J. F., Mercier, G., Cooper, P., Gastonguay, L., Morris, P., Janin, A., \& Reynier, N. (2013). Pilot-scale investigation of the robustness and efficiency off a copper-based treated wood wastes recycling process. Journal of Hazardous Materials, 261, 277-285. http://dx.doi.org/10.1016/j.jhazmat.2013.07.035.

Deramos King, C. M., Dozier, C. S., Campbell, J. L., Curry, E. D., \& Pollitt, K. J. G. (2019). Long-term leaching of arsenic from pressure-treated playground structures in the northeastern United States. The Science of the Total Environment, 656, 834-842. http://dx.doi.org/10.1016/j.scitotenv.2018.11.315.

Ferrarini, S. F. (2012). Estabelecimento de metodologia para remoção de cobre, cromo e arsênio de resíduos de madeira tratada com Arseniato de Cobre Cromatado - CCA (Tese de doutorado). Pontifícia Universidade Católica do Rio Grande do Sul, Porto Alegre.

Ferrarini, S. F., Santos, H. S., Miranda, L. G., Azevedo, C. M. N., Maia, S. M., \& Pires, M. (2016). Decontamination of CCA-treated eucalyptus wood waste by acid leaching. Waste Management, 49, 253-262. http://dx.doi.org/10.1016/j.wasman.2016.01.031.

Janin, A., Coudert, L., Blais, J. F., Mercier, G., Cooper, P., Gastonguay, L., \& Morris, P. (2012). Design and performance of a pilot-scale equipment for CCA-treated wood remediation. Separation and Purification Technology, 85, 90-95. http://dx.doi.org/10.1016/j.seppur.2011.09.052.

Jones, A. S., Marini, J., Solo-Gabriele, H. M., Robey, N. M., \& Townsend, T. G. (2019). Arsenic, copper, and chromium from treated wood products in the U.S. disposal sector. Waste Management, 87, 731-740. http://dx.doi.org/10.1016/j.wasman.2019.03.004.

Kakitani, A. T., Hata, T., Kajimoto, T., \& Imamura, Y. (2006a). A novel extractant for removal of hazardous metals from preservative-treated wood waste. Journal of Environmental Quality, 35(3), 912-917. http://dx.doi.org/10.2134/jeq2005.0318.

Kakitani, T., Hata, T., Kajimoto, T., \& Imamura, Y. (2006b). Designing a purification process for chromium, copper- and arsenic - contaminated wood. Waste Management, 26(5), 453-458. http://dx.doi.org/10.1016/j.wasman.2005.05.006.

Lebow, S., Woodward, B., Halverson, S., \& West, M. (2012). Field tests of the efficacy of zinc and fatty amine in preventing colonization by copper-tolerant fungi. International Biodeterioration \& Biodegradation, 70, 74-78. http://dx.doi.org/10.1016/j.ibiod.2012.02.003.

Matos, R. C., Oliveira, H., Fonseca, H. M. A. C., Morais, S., Sharma, B., Santos, C., \& Pereira, M. L. (2020). Comparative $\mathrm{Cr}$, As and CCA induced Cytostaticity in mice kidney: a contribution to assess CCA toxicity. Environmental Toxicology and Pharmacology, 73, 103297. http://dx.doi.org/10.1016/j.etap.2019.103297.

Mohajerani, A., Vajna, J., \& Ellcock, R. (2018). Chromated copper arsenate timber: a review of products, leachate studies and recycling. Journal of Cleaner Production, 179, 292-307. http://dx.doi.org/10.1016/j.jclepro.2018.01.111.

Ottosen, L. M., Hansen, H. K., Laursen, S., Villumsen, A. (1997). Electrodialytic remediation of soil polluted with copper from wood preservation industry. Environment Science Technology, 31, 17111715.

Pedersen, A. J., Kristensen, V., Ottosen, L. M., Ribeiro, A. B., Villumsen, A. (2005). Electrodialytic remediation of CCA-treated waste wood in pilot scale. Engineering Geology, 77, 331-338.

Ribeiro, A. B., Mateus, E. P., Ottosen, L. M., Bech-Nielsen, G. (2000). Electrodialytic Removal of Cu, Cr, and As from Chromated Copper Arsenate-Treated Timber Waste. Environmental Science and Technology. 34, 784-788.

Santos, H. S., Ferrarini, S. F., Flores, F. Q., Pires, M. J. R., Azevedo, C. M. N., Coudert, L., \& Blais, J. F. (2018). Removal of toxic elements from wastewater generated in the decontamination of CCA-treated Eucalyptus sp. and Pinus canadense wood. Journal of Material Cycles and Waste Management, 20(2), 1299-1309. http://dx.doi.org/10.1007/s10163-017-0694-1. 
Sierra-Alvarez, R. (2007). Fungal bioleaching of metals in preservative-treated wood. Process Biochemistry, 42(5), 798-804. http://dx.doi.org/10.1016/j.procbio.2007.01.019.

Xing, D., Magdouli, S., Zhang, J., \& Koubaa, A. (2020). Chemosphere microbial remediation for the removal of inorganic contaminants from treated wood: recent trends and challenges. Chemosphere, 258, 127429. http://dx.doi.org/10.1016/j.chemosphere.2020.127429.

Younis, A., Ahmadi, Z., Adams, M. G., \& Iqbal, A. (2017). A simple method for quantitative analysis of elements by XRF using variable dilution factors in fusion bead technique for geologic specimens. $X$ Ray Spectrometry, 46(1), 69-76. http://dx.doi.org/10.1002/xrs.2729.

Authors' contributions: LC: Investigation, Methodology, Project Administration, Writing; FNG: Conceptualization, Funding acquisition, Project administration; ASVSS: Data Curation, Methodology; MFS: Formal Analysis, Supervision, Software; JRVO: Visualization; Resources; RT: Ivestigation, Project Administration, Software, Supervision; PRBS: Data curation, Formal Analysis, Methodology; ADW: Visualization. 